\title{
Larger mammals of Corfu, Ionian Islands, Greece - status and potential threats
}

\author{
Marie Stille, loannis Gasteratos \& Bo Stille*
}

\begin{abstract}
The occurrence and distribution of ten larger terrestrial mammals on the Ionian Island of Corfu were investigated from January 2020 to March 2021. The northern white-breasted hedgehog and the stone marten were found to be common, and this is probably also the case for the least weasel. The red fox was primarily found in the island's rocky northeast and although not uncommon it may be under pressure as it is often considered a pest. Wild boars were found to be present, and reproduction may occur, but the status of this species needs further investigation. The Eurasian otter was found in several areas around the island, but the data indicates that the Corfu population contains few individuals that move over large areas. We suggest strengthened protection for this species to avoid further population decline and subsequent extinction. Brown hares of unknown origins are repeatedly released on the island, and in combination with extensive hunting any genetic characteristics of the indigenous population is expected to be lost. No evidence for presence of fallow deer was found, and except for photos of single specimens this was also the case for red deer and golden jackal. All investigated species are potentially threatened by habitat loss, caused by increasing tourism, extensive development, high water out-take and, in some cases, persecution.
\end{abstract}

How to cite this article: Stille M., Gasteratos I., Stille B. 2021. Larger mammals of Corfu, Ionian Islands, Greece - Status and potential threats // Russian J. Theriol. Vol.20. No.2. P.204-214. doi:10.15298/rusjtheriol.20.2.09

KEY WORDS: Erinaceus, Mustela, Martes, Lutra, Vulpes, Canis, Lepus, Sus.

MarieStille [marie.corfu@gmail.com], Kokkini Kefalovrysso 1410, 49100 Corfu, Greece, Ioannis Gasteratos, [giannis. gasteratos@gmail.com],Ag.Panteleimon,Potamos,49100Corfu, Greece,Bo Stille [stille.corfu@gmail.com],Kokkini Kefalovrysso 1410, 49100 Corfu, Greece.

\section{Крупные млекопитающие Корфу, Ионические острова, Греция - статус и потенциальные угрозы}

\author{
М. Стиллэ, И. Гастератос, Б. Стиллэ*
}

РЕЗЮМЕ. Встречаемость и распространение десяти крупных наземных млекопитающих на Ионическом острове Корфу были исследованы с января 2020 года по март 2021 года. Северный белогрудый ёж и каменная куница были обычны, то же самое относится к ласке. Обыкновенная лисица была в основном найдена на скалистом северо-востоке острова, и, хотя этот вид не является редкостью, он может преследоваться местными жителями. Было обнаружено присутствие кабанов, их размножение возможно, но статус этого вида требует дальнейшего уточнения. Выдра была обнаружена в нескольких районах острова, но исследования показали, что популяция Корфу насчитывает всего несколько особей, которые перемещаются по большой территории. Мы предлагаем усилить охрану этого вида, чтобы избежать дальнейшего сокращения популяции и последующего исчезновения. На острове неоднократно выпускали русаков неизвестного происхождения, в сочетании с интенсивной охотой мы предполагаем потерю любых генетических характеристик коренного населения. Не было обнаружено доказательств присутствия лани, за исключением фотографий единичных экземпляров, это также относится к благородному оленю и шакалу. Всем исследованным видам потенциально угрожает потеря местообитаний, вызванная ростом туризма, экстенсивным развитием, паводками и, в некоторых случаях, преследованием со стороны человека.

КЛЮЧЕВЫЕ СЛОВА: Erinaceus, Mustela, Martes, Lutra, Vulpes, Canis, Lepus, Sus.

* Corresponding author 


\section{Introduction}

Corfu (Kerkyra) is a continental island separated from the European mainland by the narrow Corfu channel (Fig. 1). The island's fauna is considered non-insular with a likely origin in the southern Balkan peninsula (Martino \& Martino, 1931; Masseti, 2012). The landscape as well as the native biocenoses of Corfu have, like in most areas in the Mediterranean, been altered by humans for millennia and both historic and recent introductions and extinctions of species have occurred (Masseti, 2012). Several Greek indigenous species have been translocated to Greek islands and rabbits, hares, and hedgehogs are examples of animals frequently introduced as a selfsustaining human food source or to enhance local game stock. (Masseti, 1998). However, the majority of Corfu's present terrestrial mammalian fauna reached the island when it was still connected to the European continent up to the end of the last glacial, approximately 10000 YBP, when it got separated due to rising sea levels.

Species such as the aurochs (Bos primigenius (Bojanus, 1827)), red deer (Cervus elaphus Linnaeus, 1758), fallow deer (Dama dama (Linnaeus, 1758)), roe deer (Capreolus capreolus (Linnaeus, 1758)), and wild boar (Sus scrofa Linnaeus, 1758) are examples of mammals from which subfossils have been found in archaeological sites from Upper Pleistocene, for summary see Gasteratos (poster at Scientific-Educational Congress Corfu 2019 on "Biodiversity: climate change and consequences on island ecosystems"). The most recent change in the mammalian composition on the island is the loss of the golden jackal (Canis aureus Linnaeus, 1758), considered extinct in the 1990s (Masseti, 2012; Gasteratos \& Fondoulakou, 2018).

It is not only the island's fauna that has changed over time, but this is also the case for habitats, especially the forests. Early in the island's history deciduous oak woodlands dominated in the fertile valleys while evergreen oaks grew in the mountains and in drier areas and conifers, such as pine and juniper, were found along the west-coast. Most of these forests were replaced by olive groves during the Venetian rule (1386-1795; Mpounias, 1958), a change in habitat that most likely has affected the island's mammalian species in different ways. Hunting has also had a crucial effect on the fauna as animals have been hunted both for food and fur, but also because they posed a threat to human interests, and the extinction of both the ungulates and the jackal most likely can be ascribed to either hunting or persecution.

Tourism and the introduction of invasive species is the latest threat to the indigenous fauna and rapid and extensive development of the island's coastal areas have resulted in destruction of several wetlands as well as fragmentation and loss of habitats in general. Although some mammalian species have been lost since the Pleistocene, the majority are still here, but some of them must be considered threatened.

No general investigation of the status and distribution of the island's mammalian fauna has been undertaken since Niethammer's survey in 1962 . However, there are

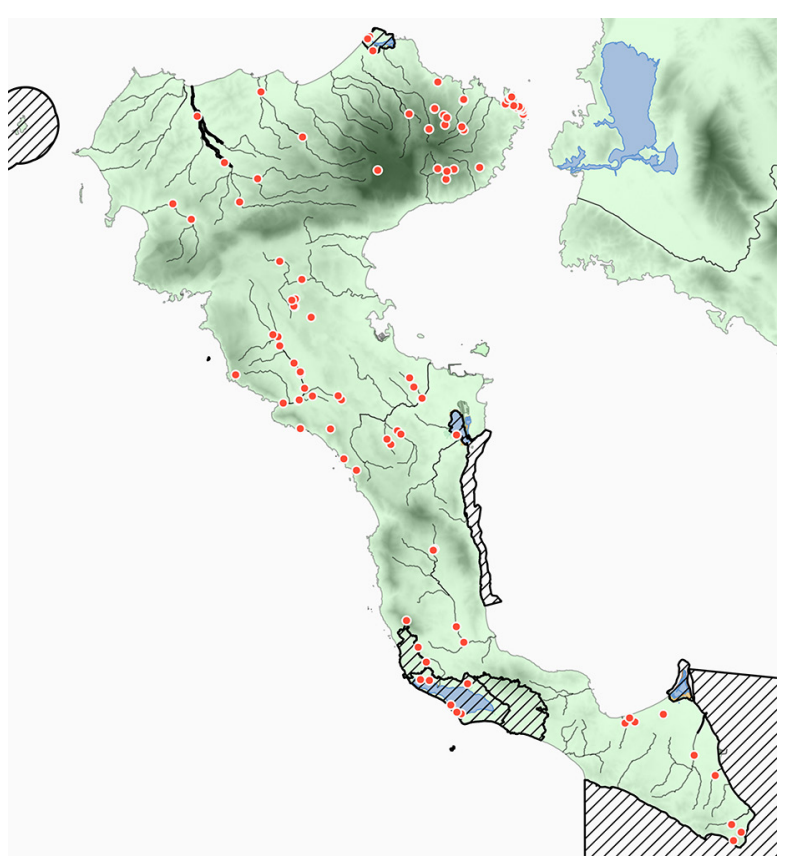

Fig. 1. Corfu is closest to the mainland (Albania) in the northeast. Dots indicate camera positions and lines Natura 2000 areas.

several studies of otters (Gaethlich, 1988; Grémillet, 1993, 1995, 1998; Urban, 1998; Ruiz-Olmo, 2006; Galanaki et al., 2019) and some reports on wild boars (Tsachalidis \& Hadjisterkotis, 2009). In this study we have investigated the status of ten of the 19 native terrestrial or semiaquatic mammals species reported in the more recent literature (Niethammer, 1962; Masseti, 2012): The northern white-breasted hedgehog (Erinaceus roumanicus Barrett-Hamilton, 1900), the European or brown hare (Lepus europaeus Pallas, 1778), the red fox (Vulpes vulpes (Linnaeus, 1758)), the stone marten (Martes foina (Erxleben, 1777)), the least weasel (Mustela nivalis Linnaeus, 1766), the Eurasian otter (Lutra lutra (Linnaeus, 1758)), the golden jackal (Canis aureus), the wild boar (Sus scrofa), red deer (Cervus elaphus) and the fallow deer (Dama dama). The main aim of this study is to gain information on the distribution, status, and habitat preference to identify possible threats, and to propose actions for the conservation or management of these species. The two invasive alien mammalian species present on Corfu, the coypu (Myocastor coypus (Molina, 1782)) and the raccoon (Procyon lotor (Linnaeus, 1758)), have recently been discussed by Stille et al. (2021).

\section{Materials and methods}

Corfu is the northernmost ( $\mathrm{N} 39.624$, E 19.922) and second largest $\left(585 \mathrm{~km}^{2}\right)$ of the main Greek Ionian Islands, at its closest situated only two km from Albania (Fig. 1). The climate is Mediterranean, i.e., with warm to hot and dry summers and cool to mild and humid winters (Csa in the Köppen-Geiger classification; Peel et al., 2007). 
Information on the distribution of the studied species was collected from January 2020 to June 2021 by direct observations in the field, including day and night road surveys, bioindicator examinations, trail camera recordings, and confirmed third party reports. Camera sites were selected using previously published reports but were also chosen to cover as many habitats as possible and to get an accurate picture of the distribution of the studied species across the island while minimising human interference. Each potential otter area was visited on several occasions, ranging from one to more than ten depending on its size, characteristics, and complexity. With special reference to otters, standard survey methods were used (Reuther et al., 2000; Mason \& Macdonald, 2009), and potential sites were regularly visited, including all areas from which otters previously have been recorded (Galanaki et al., 2019 and further references therein).

Data was classified as direct observation of individuals (O and DOR), camera recordings (C), droppings (D), tracks $(\mathrm{T})$, and signs like diggings and food remains (S) (Brown et al., 2004). All data was coded for species, age, when possible, date, and GPS coordinates (WGS84). Data points with distinct coordinates were defined as sites. Maps were created using QGIS version 3.10, and data and/or imagery from NASA's Shuttle Radar Topography Mission (SRTM), Enhanced Shuttle Land Elevation (https://www2. jpl.nasa.gov/srtm/cbanddataproducts.html).

\section{Results}

In total over 200 fieldtrips were made and, in addition to direct observations, data was obtained from recordings from a total of 13 infra-red trail cameras used at 104 sites (of which 44 were considered potential otter sites) across the island (Fig. 1), representing a total of 1682 camera recording days (of which 877 from potential otter sites). While searching for suitable camera locations many sites across the island were covered, including some $12000 \mathrm{~km}$ of road. The results are summarized in Table 1 and Figures 2-8. All reported and confirmed terrestrial mammals from 1962 to 2021 are listed in Table 2.

The northern white-breasted hedgehog (Fig. 2) is widespread on the island and found in many habitats from sea level to $650 \mathrm{~m}$ asl on Mt. Pantokratoras. 80\% of the direct observations were road killed animals (Tab. 1). Most killed animals were found around urban areas and on high traffic roads. Hedgehogs were found throughout the year, but the number of observations peaked during May and June. Only $11 \%$ of the total hedgehog observations were camera sightings.

The least weasel (Fig. 3) is one of the least encountered of the mammals in our study with only four sightings altogether and most recordings, $88 \%$, were from droppings (Tab. 1). The species has been observed across the island and is probably more common than our results suggest.

The stone marten (Fig. 4) was the most common of the investigated mammals in our study (Tab. 1) and it is spread across the island from sea level to $900 \mathrm{~m}$ asl. The animal occurs in all types of habitats and is commonly encountered, even in densely populated areas. $49 \%$ of all direct observations were road kills.

We found signs of the Eurasian otter at 72 sites (Fig. 5) and camera sightings were with one exception of single individuals. We made no direct observations, found no road kills, latrines, holts, or slides in any of the surveyed areas, and tracks along some of the sandy beaches surveyed were only found in low numbers. Of the 17 areas where otters have been reported from 1986 to 2019 , signs were detected at ten, and in addition seven

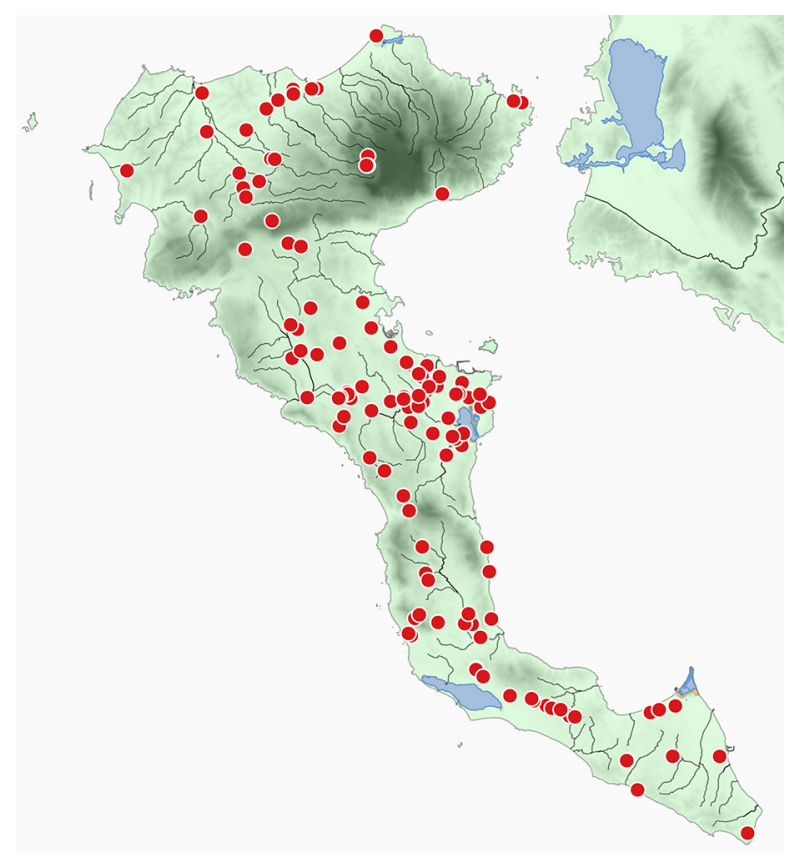

Fig. 2. Confirmed localities for Erinaceus roumanicus

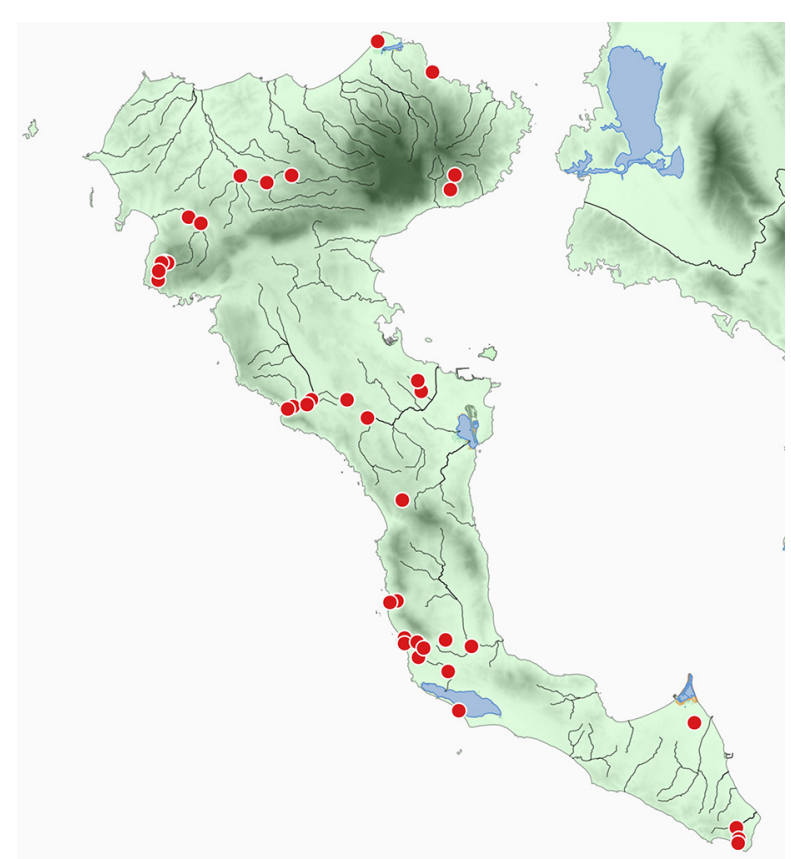

Fig. 3. Confirmed localities for Mustela nivalis. 
new sites were confirmed. $73 \%$ of the recordings were spraint, $12 \%$ tracks and $12 \%$ camera recordings (Tab. 1 ). Spraints were predominantly found on rocks $(75 \%)$ and logs $(18 \%)$, but in total they were relatively few (77) compared to the 91 found by Ruiz-Olmo during a much shorter spring survey in 2006 . No detailed spraint analysis was made, but in the spraint examined fish scales dominated, frog/toad bones were included in a few, and in one case small passerine feathers were found. For a previous diet analysis, see Ruiz-Olmo (2006).

Signs of the red fox (Fig. 6) were found across the island except for the far south, but most observations were made by trail cameras in the mountains in the northeast. Only 31 direct observations were made of which four $(13 \%)$ were road kills (Tab. 1). Most observations of

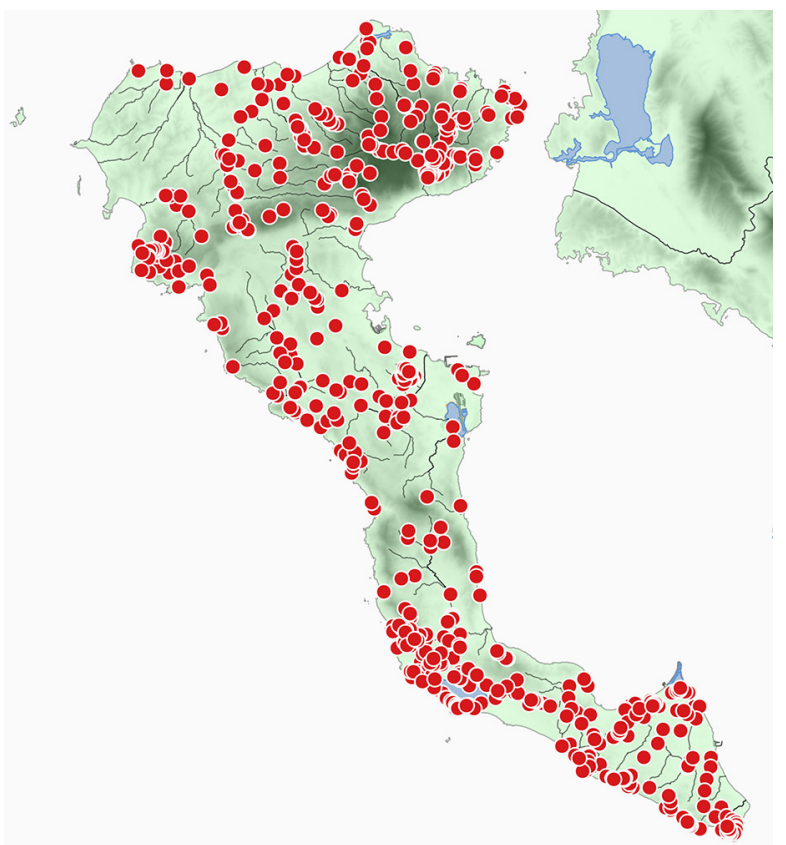

Fig. 4. Confirmed localities for Martes foina. foxes were made in less densely populated areas on the mountains, but they were also encountered close to beaches, riverbeds, ponds, and in a few cases in gardens.

With respect to the golden jackal, there are six unconfirmed reports from 2020. These reports were made mostly by locals (hunters, shepherds, and forest rangers) and include alleged howling as well as sightings. No howling was detected during our nightly excursions and no other signs were found. In January 2020, an adult specimen was photographed in north-eastern Corfu (E. Sarakinou, pers.com., Fig. 7). It seemed to have been stressed and had some minor injuries, but after being offered food, it disappeared.

The brown hare (Fig. 8) can be found in low numbers across the island, from sea level to approximately

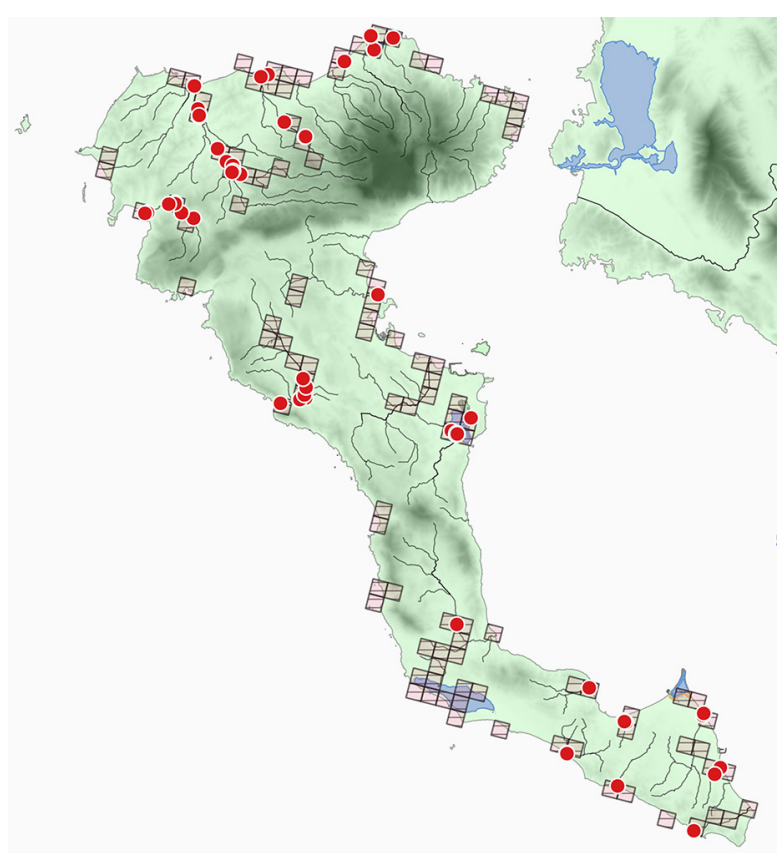

Fig. 5. Confirmed localities for Lutra lutra (dots). Squares $(1 \times 1 \mathrm{~km})$ indicate areas specifically searched for otters.

Table 1. Recordings of the larger mammals in Corfu during 2020-2021.

Sites $=$ registered coordinates; Observations $=$ direct observations of live specimens; $D O R=$ dead on road; Cam \%=percent of total 104 camera locations (of which 44 in potential otter habitats); Cam days=days with recordings (percent of total 1682 days, 877 of which were from the 44 potential otter habitats); Cam recs=total number of recordings; $\mathrm{S}=$ other signs; $*=$ additional reports/photos from locals.

\begin{tabular}{|l|c|c|c|c|c|c|c|c|c|}
\hline \multicolumn{1}{|c|}{ Species } & Sites & Observations & DOR & Cam \% & Cam days (\%) & Cam recs & Droppings & Tracks & S \\
\hline E. roumanicus & 122 & $20\left(5^{*}\right)$ & 99 & 7.2 & $10(0.6)$ & 15 & 4 & 1 & 0 \\
\hline M. nivalis & 35 & $1\left(1^{*}\right)$ & 2 & 1.0 & $1(0.1)$ & 1 & 36 & 0 & 0 \\
\hline M. foina & 567 & $89\left(9^{*}\right)$ & $93\left(1^{*}\right)$ & 42.3 & $148(8.8)$ & 622 & $421\left(9^{*}\right)$ & 46 & 0 \\
\hline L. lutra & 72 & $0\left(0^{*}\right)$ & 0 & 7.3 & $6(0.7)$ & 13 & 77 & 13 & 2 \\
\hline V. vulpes & 140 & $7\left(20^{*}\right)$ & $2\left(2^{*}\right)$ & 23.7 & $63(3.7)$ & 302 & $79\left(4^{*}\right)$ & $27\left(4^{*}\right)$ & 2 \\
\hline C. aureus & 1 & $0\left(1^{*}\right)$ & 0 & 0 & $0(0)$ & 0 & 0 & 0 & 0 \\
\hline L. europaeus & 36 & $21\left(6^{*}\right)$ & 1 & 2.1 & $4(0.3)$ & 7 & 14 & 2 & 0 \\
\hline S. scrofa & 23 & $1\left(10^{*}\right)$ & 0 & 0 & $1(0.1)$ & 11 & $3(1 *)$ & 1 & $19\left(3^{*}\right)$ \\
\hline C. elaphus & 2 & $0\left(2^{*}\right)$ & 0 & 0 & 0 & 0 & 0 & 0 & 0 \\
\hline
\end{tabular}


Table 2. Terrestrial mammals reported from Corfu 1962-2021.

$\mathrm{N}=$ Not confirmed; $\mathrm{C}=$ Confirmed; $*=$ single specimen observed; $* *=$ Only domesticated; $* * *=$ Free ranging on the islet of Vido; $\uparrow=$ considered extinct. Previous reports: 1 - Niethammer, 1962; 2 - Masseti, 2012; 3 - Galanaki et al., 2019; 4 - Stille \& Stille, 2017; 5 - Stille et al., 2021.

\begin{tabular}{|c|c|c|c|c|}
\hline Family & \multicolumn{2}{|c|}{ Species } & $\begin{array}{c}\text { Previous } \\
\text { reports }\end{array}$ & $\begin{array}{c}\text { Present } \\
\text { study }\end{array}$ \\
\hline \multicolumn{5}{|c|}{ Native } \\
\hline Erinaceidae & $\begin{array}{l}\text { Erinaceus roumanicus Barrett-Hamilton, } \\
1900\end{array}$ & northern white-breasted hedgehog & $1,2,4$ & $\mathrm{C}$ \\
\hline \multirow[t]{2}{*}{ Soricidae } & Crocidura suaveolens (Pallas, 1811) & lesser white-toothed shrew & 1,2 & $\mathrm{C}$ \\
\hline & Suncus etruscus (Savi, 1822) & pygmy white-toothed shrew, Etruscan shrew & 1,2 & C \\
\hline Talpidae & Talpa stankovici Martino \& Martino, 1931 & Balkan mole, Stankovic's mole & 1,2 & $\mathrm{C}$ \\
\hline Leporidae & Lepus europaeus Pallas, 1778 & European hare, brown hare & 1,2 & C \\
\hline \multirow[t]{6}{*}{ Muridae } & Apodemus flavicollis (Melchior, 1834) & yellow-necked mouse & 1,2 & $\mathrm{C}$ \\
\hline & $\begin{array}{l}\text { Apodemus mystacinus Danford } \\
\text { \& Alston, } 1877\end{array}$ & $\begin{array}{l}\text { rock mouse, } \\
\text { eastern broad-toothed field mouse }\end{array}$ & 1,2 & $\mathrm{~N}$ \\
\hline & Apodemus sylvaticus (Linnaeus, 1758) & wood mouse & 1,2 & $\mathrm{~N}$ \\
\hline & Mus musculus Schwarz \& Schwarz, 1943 & house mouse & 1,2 & $\mathrm{C}$ \\
\hline & Rattus norvegicus (Berkenhout, 1769) & black rat, ship rat & 1,2 & $\mathrm{C}$ \\
\hline & Rattus rattus (Linnaeus, 1758) & brown rat & 1,2 & $\mathrm{C}$ \\
\hline \multirow[t]{2}{*}{ Gliridae } & $\begin{array}{l}\text { Muscardinus avellanarius } \\
\text { (Linnaeus, 1758) }\end{array}$ & hazel dormouse & 1,2 & $\mathrm{C}$ \\
\hline & Glis glis (Linnaeus, 1766) & fat dormouse, edible dormouse & 1,2 & $\mathrm{C}$ \\
\hline Suidae & Sus scrofa Linnaeus, 1758 & wild boar & $2 \dagger$ & $\mathrm{C}$ \\
\hline \multirow[t]{2}{*}{ Cervidae } & Dama dama (Linnaeus, 1758) & fallow deer & Unpubl. & $\mathrm{N}$ \\
\hline & Cervus elaphus Linnaeus, 1758 & red deer & - & $\mathrm{C}^{*}$ \\
\hline \multirow[t]{3}{*}{ Mustelidae } & Mustela nivalis Linnaeus, 1766 & weasel, least weasel & $1,2,4$ & $\mathrm{C}$ \\
\hline & Martes foina (Erxleben, 1777) & stone marten, beach marten & $1,2,4$ & C \\
\hline & Lutra lutra (Linnaeus, 1758) & Eurasian otter & $1,2,3$ & C \\
\hline \multirow[t]{2}{*}{ Canidae } & Vulpes vulpes (Linnaeus, 1758) & red fox & 1,2 & C \\
\hline & Canis aureus Linnaeus, 1758 & golden jackal, Asian Jackal & $1,2 \dagger, 5 \dagger$ & $\mathrm{C}^{*}$ \\
\hline \multicolumn{5}{|c|}{ Introduced } \\
\hline Procyonidae & Procyon lotor (Linnaeus, 1758) & raccoon & 5 & $\mathrm{C}$ \\
\hline Echimyidae & Myocastor coypu (Molina, 1782) & coypu, nutria & 5 & $\mathrm{C}$ \\
\hline Hystricidae & Hystrix indica Kerr, 1792 & Indian crested porcupine & 5 & $\mathrm{~N}$ \\
\hline Sciuridae & Tamias sibiricus (Laxmann, 1769) & Siberian chipmunk & 5 & $\mathrm{~N}$ \\
\hline Leporidae & Oryctolagus cuniculus (Linnaeus, 1758) & European rabbit & $1 * *, 2 * *$ & $\mathrm{C}^{* * *}$ \\
\hline
\end{tabular}

$900 \mathrm{~m}$ asl, but direct observations are few, and the number of camera recordings is also low (Tab. 1). Most observations were from the Pantokrator mountain range in the northeast, and there are only few sightings from cultivated areas. Also, very few droppings were found in any of the searched habitats.

During 2020, we obtained signs and reports of observations of boars from three areas on the island and one animal was reported swimming $10 \mathrm{~km}$ out to sea near the Lefkimmi area in the south (Miltiadis, 2020). Signs of boars were confirmed for 23 sites, and observations of piglets were made at three localities, including one by D. King (pers. com).

We found no signs of fallow deer on the island, and the forest ranger responsible for the area with the most recent sightings claimed the animals observed during 2016 and 2017 were shot. A single adult female red deer was photographed in the northeast in July and August 2021.

\section{Discussion}

Three species in our study, the White-breasted Hedgehog, the least weasel, and the stone marten must be considered to have viable populations, and not being threatened. The northern white-breasted hedgehog, the second most encountered species in our study, often falls victim to traffic, and it is the most encountered roadkill on Corfu (Tab. 1). Despite this, the animal is spread across the island and is found from sea level to at least $650 \mathrm{~m}$ asl. The least weasel does not seem to be common, but its abundance and distribution may be underestimated, and more studies of more specific sites/habitats are needed to get an accurate picture of its status. Weasels are relatively small and very quick animals and difficult to catch on camera. However, it is possible that there is interspecific competition between weasels and martens as they, at least partly, share the same trophic niche (Padial et al., 2002; Lanszki \& Heltai, 2007). 


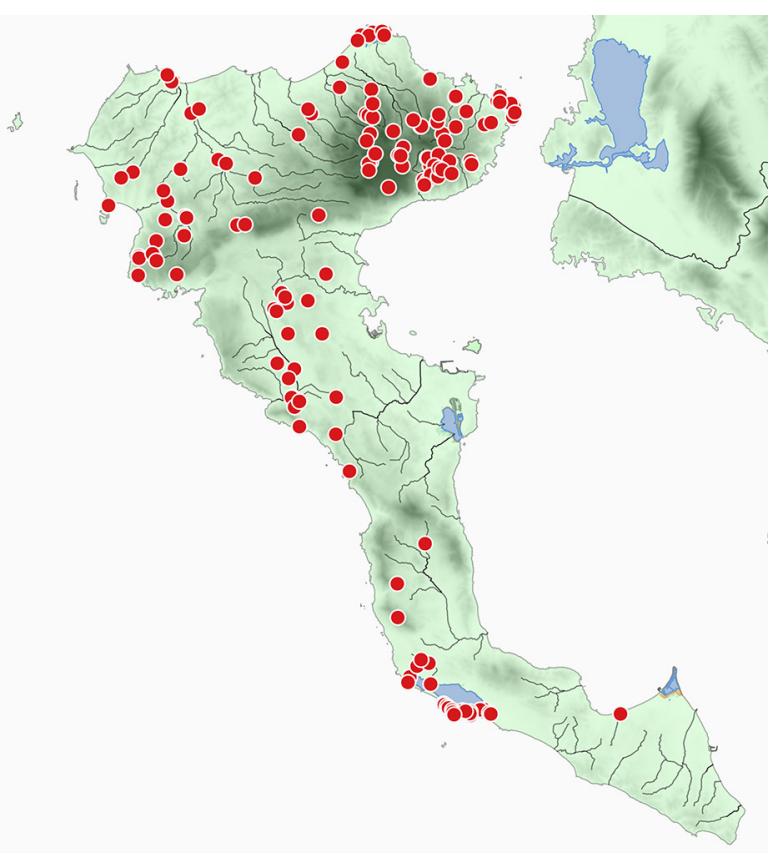

Fig. 6. Confirmed localities for Vulpes vulpes.

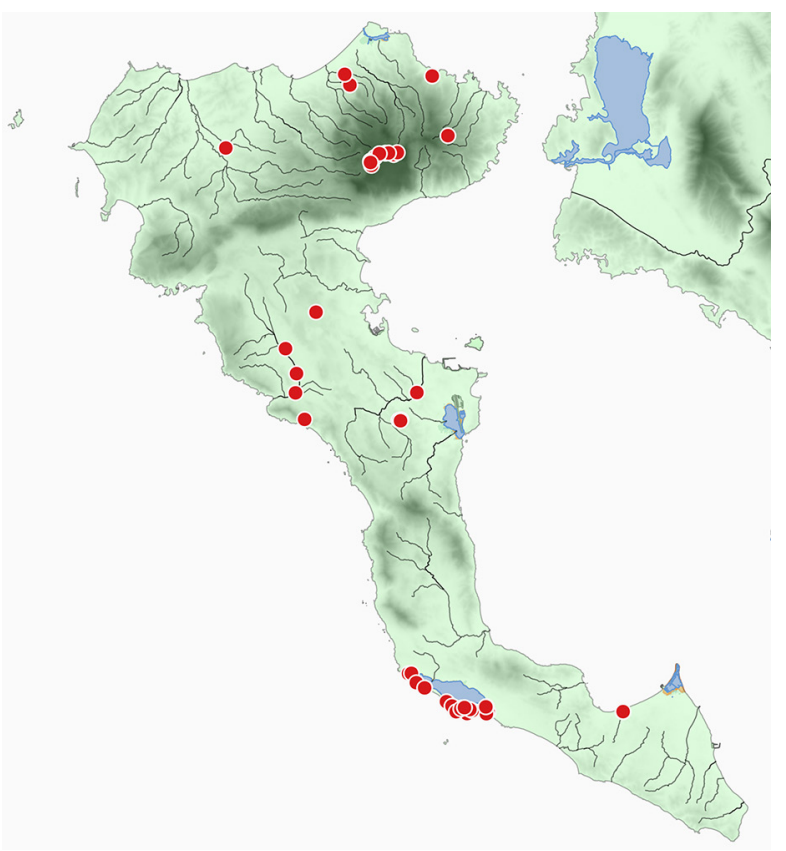

Fig. 8. Confirmed localities for Lepus europaeus.

The stone marten is by far the most frequently encountered species in our study, and it can be found in all types of habitats, often close to human settlements, across the island. It seems to prefer open habitats (Aulagnier et al., 2009; Herr et al., 2009a, b), and the temporal distribution of subfossil records in Europe during Holocene suggest that the opening of the landscape by humans during this period favoured stone martens and aided their expansion into Europe from western Asia

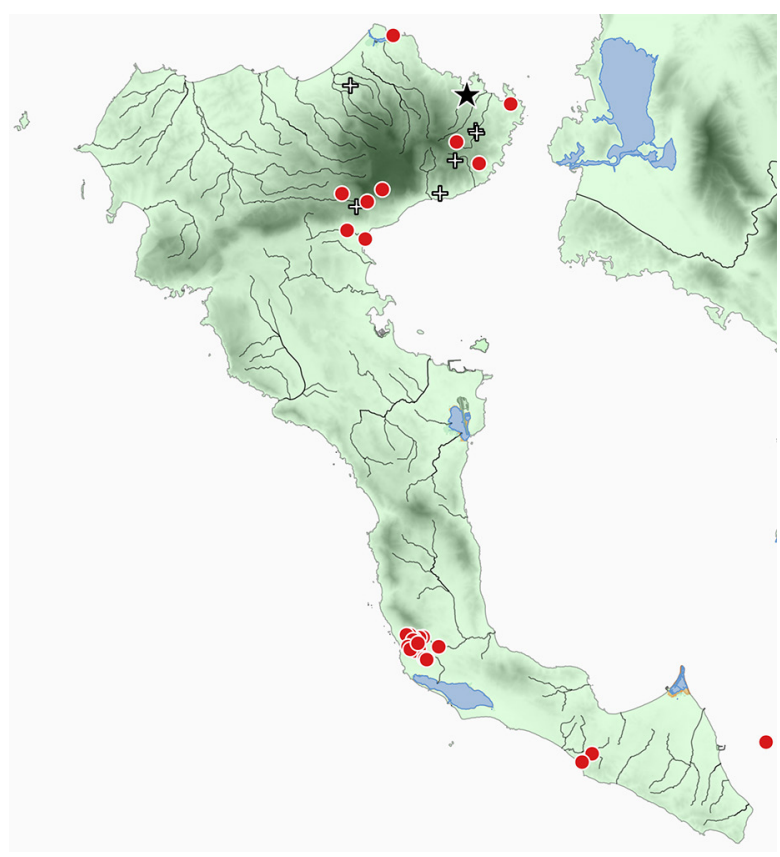

Fig. 7. Locality for photos of single specimen of Canis aureus (star) and unconfirmed reports (cross) from 2020. Confirmed localities for Sus scrofa are indicated by dots.

(Anderson, 1970; Sommer \& Benecke, 2004). Stone martens are opportunistic in their food choice (Aulagnier et al., 2009), and a wide diet overlap has been found between martens and foxes (Serafini \& Lovari, 1993). However, martens apparently do not scavenge for food (Herr et al., 2009a, b). It is possible that the ability to adapt to human altered environments is the main factor behind the large number of martens found on Corfu. However, decline in interspecific competition by the absence of jackals and the relatively low number of foxes may also contribute to the stone marten's success, making it the island's major indigenous mammalian predator.

The otter is considered Endangered in Greece and is included in Annexes II and IV of the European Habitat Directive (92/43/EEC) (Legakis \& Maragos, 2009; Duplaix \& Savage, 2018). It is protected in Special Areas of Conservation of the Natura 2000 Network (European Environment Agency, 2015), listed in Appedix I of CITES, and included in the Bern Convention (Roos et $a l ., 2015)$. It is the only mammal in our study that has been subject to several previous investigations (see Galanaki et al., 2019). It was mentioned as rare already by Heldreich (1878), it has been hunted for fur in the wetlands around Antinioti lagoon (Mpounias, 1958), in the Potamos (G. Trikaliotis, pers. com.), and in other rivers on the island (Niethammer, 1962). It has been accidentally caught in eel traps in the Chalikiopoulou lagoon (former lagoon guardian, pers. com.) and has been reported from the Melissi and Gritis streams in the 1940s and 1960s (R. Gasteratou, pers. com.). Judging from earlier studies it can be concluded that the otter on Corfu has been under pressure and the population 
dwindling for a long time. Furthermore, none of the many proposals issued for its conservation on the island have so far been implemented.

The comparatively low number of otter signs recorded in our study indicates that otters are rare and that individuals move over large areas. Scattered spraint was found at Megapotamos, but no otters were registered despite a total of 161 camera days from two sites along the stream. Spraint was also found at Ropa river, but otter was only registered once during 127 camera days. However, seasonal factors may also play a role in how and when individuals move as part of rivers and wetlands dry out in summer.

Corfu used to be rich in otter habitats, but many wetlands have been lost, and large parts of the coast have been developed for the tourist trade, severely restricting access to estuaries and rivers. This has led to loss and fragmentation of habitats and made it difficult for otters, which generally have large home-ranges, to move between suitable habitats (Erlinge, 1967). Furthermore, two of the four Natura 2000 sites designated as protected areas for this species are small, each only covering an area of about two $\mathrm{km}^{2}$.

This is the case for Antinioti lagoon (GR 2230001, 19 ha), a saltwater lagoon surrounded by brackish marshland fed by freshwater, mainly from precipitation but also from springs and a small stream. The lagoon is rich in food, have areas suitable for nesting and the water is permanent. However, there is a sharp increase in tourist developments along the north coast and the area around the lagoon making it more and more difficult for otters to disperse or move between suitable habitats. Otters are secretive animals sensitive to human disturbance (Duplaix \& Savage, 2018) and as new holiday accommodations are built close to the small lagoon this is bound to have an adverse effect. However, this Natura 2000 site is still one of the best areas for otters on the island.

The Tiflos or Fonissa river, recently added to the Natura 2000 network (GR2230009, 81 ha), is situated some $13 \mathrm{~km}$ west of the lagoon on the north coast and this river with its tributaries is another crucial area for the island's otters. Unfortunately, the protection includes only part of the river system. The river is long, relatively unpolluted, and contains water during large parts of the year. It has a broad river mouth with plenty of fish and it is also rich in prey such as amphibians and crabs that can sustain otters during part of the year.

The area around Alikes Lefkimmi (GR2230003, $213 \mathrm{ha}$ ) is less developed and it should be possible for otters to move along the coast utilizing the small estuaries and wetlands, but signs of otters here are few. It is possible that if the undeveloped coastal area between Alikes Lefkimmi and the Lefkimmi river were to be protected, the latter recently added to the Natura 2000 network (GR2230004), this area could support a growing otter population.

Otters were also registered in the Chalikiopoulou lagoon, a marine habitat surrounded by both brackish and freshwater wetlands and rich in prey. This area probably once was one of the better habitats for the species on the island, and in 1992 Grémillet and Walmsley proposed a restoration plan as they considered this wetland to be of international importance. The lagoon itself, but not the surrounding marshlands, is included in a larger Natura 2000 site (GR2230005, 867 ha). However, the island's airport is situated here, and the area is under pressure from pollution and development. The Korission lagoon (GR2230002, 2317 ha) is also a large Natura 2000 site, but otters have not been reported here since 2006 (Galanaki et al., 2019).

As otters can utilize both brackish and marine habitats it has been suggested that there might be gene flow between mainland and island populations (Ruiz-Olmo, 2006), but at present there is no evidence for recolonization and further studies are needed to establish if this occurs. The otters on Corfu are undoubtedly subjected to several threats. The species needs to be regularly monitored, its protection status upgraded, and a strong focus on habitat protection is essential to ensure its survival on the island.

We found signs of red fox across the island in a variety of habitats, most frequently in the mountains in the northeast. Beaches, shrubbery, open grassland, and dry riverbeds were some of the habitats used by the foxes in our study. The species is listed as Least Concern by IUCN and it is the most common canine species in Greece (Papageorgiou et al., 1988). However, the red fox is, by many, still viewed as a pest, persecuted, and wrongly accused of being a major predator on livestock. Between 1971 and 19772266 individuals were killed on Corfu and presented to the forestry service (Department of Forestry of Corfu Chronicle Book 1942-1992; Papageorgiou et al., 1988). Fewer recordings were made of foxes compared to martens and this may simply be due to differences in population structure, i.e. martens may generally have denser populations, but interspecific competition may also play a role (Serafini \& Lovari, 1993). It may also be that the red fox is considered more of a pest and therefore subjected to targeted persecution such as illegal poisoning, but we have no direct evidence for this. However, more than 250 larger carnivores were reported to have been killed by poisoning on Corfu between 2000 and 2016 (Ntemiri et al., 2018).

The golden jackal used to have its European stronghold in the Balkans, including Greece. However, the species has recently expanded rapidly in Europe (Arnold et al., 2012; Spassov \& Acosta-Pancov, 2019), while there has been a drastic decline in Greek populations (Giannatos et al., 2005). This decline has been attributed to a change in agro-pastural practices, reduction of availability of day-cover, and a decline in basic food items (Giannatos et al., 2010). Jackals were reported to be common on Corfu until the early 1960s, after which the species gradually declined, and the last confirmed observation was made in 1993 (see Gasteratos \& Fondoulakou, 2018). However, during the last 20 years, and especially in the last five, unconfirmed sightings and signs indicating jackal presence have been reported, and a single individual was photographed in 
2020. The origin of this specimen is unknown, but as jackals are reported to be good swimmers (Spassov \& Acosta-Pancov, 2019), it most likely swam from the Butrint area in Albania. However, as only one specimen has been documented, a natural recolonisation of the island seems unlikely, especially considering loss of suitable habitats and potential human-carnivore conflicts on the island.

The brown hare is listed as protected in Annex III of the Bern Convention, but considered as Least Concern by the IUCN (Vaughan et al., 2003). However, populations have diminished in some areas in Europe due to intensification of agricultural practises and loss of habitat (Smith et al., 2005; Sliwinski et al., 2019). The low number of hares found in our study can most likely be ascribed to high hunting pressure and not to habitat loss as agricultural mosaics, grasslands, shrubberies, and open olive groves are relatively common on the island. Frequent translocations pose another threat to the brown hare as it is considered one of the most translocated mammals in Europe (Kasapidis et al., 2005), and in several countries original local populations have been replaced by individuals from other parts of Europe (Flux, 1983; Mamuris et al., 2001). Regular translocations of reared animals can potentially replace local gene pools, reduce genetic variability, and threaten the long-term viability of the species (Flux, 1983; Perez-Suarez et al., 1994; Pierpaoli et al., 1999). According to Mamuris et al. (2002), the practise of releasing reared hares of mixed European origin in Greece may have affected population structures and increased the potential risk for spreading haemorrhagic virus in Greece. This calicivirus disease, which is usually fatal, causes acute pulmonary haemorrhage and hepatitis in lagomorphs (Le GallReculé et al., 2017; Bel et al., 2019).

Translocation of hares to Corfu for hunting purpose occurs frequently and a total of 552 individuals were introduced by the island's Hunting Association between 2012 and 2020 (release decisions Ministry of Digital Governance, https://diavgeia.gov.gr/). It is worth noting that some of the introduced animals were released in the Pantokratoras and Agios Matteos Wildlife Refuges where hunting is prohibited. Unfortunately, we have no recent data, but as many as 600 individuals were reported to be killed each year by the island's hunters in the 1960s (Niethammer, 1962). Due to high hunting pressure and a frequent release of individuals with undocumented origin, the original gene pool of the hares on Corfu is most likely lost or at least severely altered. However, if the animals released in the two wildlife refuges are left to reproduce without interference it is possible that the species can establish a viable population that in time can spread across the island and be used as game for sustainable hunting.

The wild boar is widespread in continental Greece and the species was present on Corfu during upper Pleistocene (Sordinas, 1969), but it was probably hunted to extinction or near extinction early on. There is no reference of boar occurrence in the literature since Theotokes (1826), but it reappeared on the island in the 1980s by swimming from Albania, most likely because of hunting pressure in the Kasmil area (G. Trikaliotis, pers.com.). There are several reports of boars entering the island by swimming the narrow Corfu strait, and in 1984 a group of eight individuals were reported to cross from the Butrint region (Department of Forestry of Corfu). One animal is also reported to have entered the island in the south by swimming $10 \mathrm{~km}$ from Epirus in 2019 (G. Trikaliotis, pers.com.), and a second individual was photographed doing the same in 2020 (Miltiadis, 2020). Thus, recolonization from the mainland to the east coast of the island may consequently occur on a regular basis.

Animals have also been deliberately released in several places by the Hunting Association of Corfu (Department of Forestry of Corfu, G. Trikaliotis, pers. com.) and hunting was prohibited during the huntingseason of 1993-1994 to promote population growth (Papageorgiou, 1996). The ban was lifted in 2000 by the Department of Forestry due to complaints from farmers, and by 2004 the species appeared to have been exterminated as no animals were reported to Tsachalidis \& Hadjisterkotis (2009). However, boars are occasionally kept in enclosures on the island and some of these animals are known to have escaped and become established.

It seems clear that there is an influx of wild boars from the mainland, and the recording of juveniles indicates reproduction in the wild. Reintroductions of boars have caused conflicts with humans in many areas in Europe where the animals have caused severe damage, especially when released in areas where there are no predators and hunting is insufficient (Massei \& Genov, 2004; Massei et al., 2015). Boars are crepuscular, secretive, and highly reproductive and they prefer shrubland and open woodlands but can be found in a diversity of habitats. Even if indigenous, they need to be closely monitored when introduced to for example agricultural or high traffic areas where they may cause problems (Tack, 2018)

Subfossils of fallow deer and red deer from the palaeolithic and Neolithic period have been found on Corfu (Sordinas, 1969; Dermitzakis \& Sondaar, 1985; Dermitzakis \& Drinia, 2004), but these species were most likely hunted to extinction quite early in the island's "modern" history. As there is no evidence for these species in the coastal area on the mainland opposite Corfu (Prigioni, 1996; Masseti \& Mertzanidou, 2008), we conclude that the animals sighted had escaped from captivity and that there are still animals kept in private enclosures on the island.

\section{Conclusions}

Loss and fragmentation of habitats are the two main threats to most of the animals in our study, but hunting, pollution, and illegal persecution are other potential threatening factors. The seemingly uncontrolled growth of the tourism sector with new hotels and other accommodations constructed close to, or even inside, protected Natura 2000 areas give little room for wildlife. It is important to stress that without adequate information, 
implementation, and enforcement, regulations have little or no effect in protecting species and habitats. Species such as the otter are in critical need of habitat protection, and an overall plan for the management of protected areas and other suitable otter habitats on the island is urgently needed. Furthermore, all animals in our study would benefit from further studies to secure suitable habitats and safeguard the islands biodiversity.

ACKNOWLEDGEMENTS. We are grateful for information obtained from the Corfu Department of Forestry, A. Galanaki, A. Pouliasi, D. King, E. Sarakinou, G. Trikaliotis, K. Sarakinos, M. Nikolouzou, R. Gasteratou, S. Tsirigoti, T. Kominos, and the former guardian of Chalikiopoulou Lagoon (anonymous), and to Costas Kaloudis (IEF) for his support throughout the project. This study was supported by a grant from The Ionian Environment Foundation. The funders had no role in study design, data collection and analysis, decision to publish, or preparation of the manuscript. This study was conducted under Greek permit YПEN/ $\Delta \Delta \Delta$ 122530/1781/23-12-19 (A $\Delta \mathrm{A}$ : $\Omega \Xi K O 4653 \Pi 8-\mathrm{P} \Omega Z$ ).

\section{References}

Anderson E. 1970. Quaternary evolution of the genus Martes (Carnivora, Mustelidae) // Acta Zoologica Fennica. Vol.130. P.1-132.

Arnold J., Humer, A., Heltai M., Murariu D., Spassov N. \& Hackländer K. 2012. Current status and distribution of golden jackals Canis aureus in Europe // Mammal Review. Vol.42. P.1-11.

Aulagnier S., Haffner P., Mitchell-Jones A.J., Moutou F. \& Zima J. 2009. Mammals of Europe, North Africa and the Middle East. London: A and C Black Publishers Ltd. 272 p.

Bel D. J., Davis J. P., Gardner M., Barlow A. M., Rocchi M., Gentil M. \& Wilson R. J. 2019. Rabbit haemorrhagic disease virus type 2 in hares in England // Veterinary Record. Vol.184. P.127.

Brown R.W., Lawrence M.J., \& Pope J. 2004. Animals: tracks, trails and signs. Hamlyn Guide, London: Bounty Books. $320 \mathrm{p}$.

Dermitzakis M.D. \& Drinia H. 2004. Pelaeogeographic evolution of Ionian Islands during upper Cenozoic Era // Conference abstract book Prehistoric Corfu and its surroundings. Problems - Prospects. P.49-57 [in Greek].

Dermitzakis M.D. \& Sondaar P.Y. 1985. The Quaternary Fossil Mammals from North-eastern of Kerkyra (Corfu) Island (Ionian Sea, Greece) // Rapports et procès verbaux des réunions - Commission internationale pour l'exploration scientifique de la Mer Méditerranée. Vol.29. P.155-156.

Duplaix N. \& Savage M. 2018. The global otter conservation strategy. Salem, Oregon, USA: IUCN/SSC Otter Specialist Group. 166 p.

Erlinge S. 1967. Home range of the otter Lutra lutra L. in Southern Sweden // Oikos. Vol.18. P.186-209.

European Environment Agency (EEA). 2015. Sites of Community Importance (SCI) designated for the Eurasian otter (Lutra lutra) in the EU-27 and its current distribution in EU-25 Member States. https://www.eea.europa.eu/ data-andmaps/figures/sites-of-community-importance-sci

Flux J.E.C. 1983. Introduction to taxonomic problems in hares // Acta Zoologica Fennica. Vol.174. P.7-10.

Galanaki A., Kominos T., Zogaris S., Gasteratos I., \& Lymberakis P. 2019. Presence of the Eurasian otter Lutra lutra on the islands of Greece: a review // Journal of Vertebrate Biology. Vol.68. P.246-252.

Gasteratos I. \& Fondoulakou Z. 2018. The presence and the extinction of the golden jackal from the island of Corfu, north-western Greece // Hellenic Zoological Archives. No.9. P.86.

Giannatos G., Marinos Y., Maragou P. \& Catsadorakis G. 2005. The status of the Golden Jackal (Canis aureus L.) in Greece // Belgian Journal of Zoology. Vol.135. P.145-149.

Giannatos G., Karypidou A., Legakis A. \& Polymeni R. 2010. Golden jackal (Canis aureus) diet in Southern Greece // Mammalian Biology. Vol.75. P.227-232.

Gaethlich M. 1988. Otters in Western Greece and Corfu // IUCN Otter Specialist Group Bulletin. Vol.3. P.17-23.

Grémillet X. \& Walmsley J. 1992. The Chalkiopoulos Lagoon, Corfu, Greece. A restoration proposal for a wetland of international importance. Saint-Maximin, France: Corfu Association for the Safeguard of the Chalkiopolous Lagoon and Medmaravis. $14 \mathrm{p}$.

Grémillet X. 1993. Field survey of Lutra lutra on Corfu Island (Ionian Sea, Greece) // IUCN Otter Specialist Group Bulletin. Vol.8. P.39-42.

Grémillet X. 1995. Proposal for the conservation of Lutra lutra on Corfu Island (Ionian Sea, Greece) // Hystrix. Vol.7. P.219-222.

Grémillet X. 1998. Otter (Lutra lutra) surveys on Corfu Island and at lakes Prespa, Greece // Dulfer R., Conroy J.H., Nel J. \& Gutleb A.C. (eds.). Proceedings of the 7th International Otter Colloquium 14-19/03/1998, Třeboň, Czech Republic. IUCN Otter Specialist Group Bulletin. Vol.19A. P.96-99.

Heldreich de T.H. 1878. La Faune de Grèce. Rapport sur les travaux et recherches Zoologiques faites en Grèce et revue sommaire des animaux qui se $y$ trouvent naturellement ou à l'état de domesticité. Athenes: Impremiere de la philocalie. 128 p. [in French].

Herr J., Schley L. \& Roper T.J. 2009a. Socio-spatial organization of urban stone martens // Journal of Zoology. Vol.277. P.54-62.

Herr J., Schley L. \& Roper T.J. 2009b. Stone martens (Martes foina) and cars: investigation of a common human-wildlife conflict // European Journal of Wildlife Research. Vol.55. P.471-477.

Kasapidis P., Suchentrunk,F., Magoulas A. \& Kotoulas G. 2005. The shaping of mitochondrial DNA phylogeographic patterns of the brown hare (Lepus europaeus) under the combined influence of Late Pleistocene climatic fluctuations and anthropogenic translocations // Molecular Phylogenetics and Evolution. Vol.34. P.55-66.

Lanszki J. \& Heltai M. 2007. Diet of the weasel in Hungary // Folia Zoologica. Vol.56. P.109-112.

Legakis A. \& Maragos P. 2009. The Red Book of endangered animals of Greece. Athens: Hellenic Zoological Society. $525 \mathrm{p}$.

Le Gall-Reculé G., Lemaitre E., Bertagnoli S., Hubert C., Top S., Decors A., Marchandeau S. \& Guitton J.-S. 2017. 
Large-scale lagovirus disease outbreaks in European brown hares (Lepus europaeus) in France caused by RHDV2 strains spatially shared with rabbits (Oryctolagus cuniculus) // Veterinary Research. Vol.48. P.1-9.

Mamuris Z., Sfougaris A.I. \& Stamatis C. 2001. Genetic structure of Greek brown hare (Lepus europaeus) populations as revealed by mtDBNA RFLP-PCR analysis: implications for conserving genetic diversity // Biological Conservation. Vol.101. P.187-196.

Mamuris Z., Athanasios I., Sfougaris A.I., Stamatis C. \& Suchentrunk F. 2002. Assessment of Genetic Structure of Greek Brown Hare (Lepus europaeus) Populations Based on Variation in Random Amplified Polymorphic DNA (RAPD) // Biochemical Genetics. Vol.40. P.323-338.

Mason C.F. \& Macdonald S.M. 2009. Otters: ecology and conservation. Cambridge: Cambridge University Press. 261 p.

Martino V. \& Martino E. 1931. A New Form of Mole from Jugoslavia // Journal of Mammalogy. Vol.12. P.53.

Massei G.I. \& Genov P.V. 2004. The environmental impact of wild boar // Galemys. Vol.16. P.135-45.

Massei G., Kindberg J., Licoppe A., Gačić D., Šprem N., Kamler J., Baubet E., Hohmann U., Monaco A., Ozoliņš J. \& Cellina S. 2015. Wild boar populations up, numbers of hunters down? A review of trends and implications for Europe // Pest Management Science. Vol.71. P.492-500.

Masseti M. 1998. Holocene and anthropochorous wild mammals of the Mediterranean islands // Anthropozoologica. Vol.28. P.3-20.

Masseti M. 2012. Atlas of Terrestrial Mammals of the Ionian and Aegean Islands. Berlin: De Gruyter, GmbH. 302 p.

Masseti M. \& Mertzanidou D. 2008. Dama dama. The IUCN Red List of Threatened Species 2008:e. T42188A10656554. DOI:10.2305/IUCN.UK.2008. RLTS.T42188A10656554.en.

Miltiadis D. 2020. [The boar that sailed to Corfu] // Hunting News. Vol.365. P.6-7 [in Greek].

Mpounias I. 1958. [Kerkiraika: History and folklore. Vol. II Corfu.] Corfu. 285 p [in Greek].

Niethammer J. 1962. Die Säugetiere von Korfu // Bonner zoologische Beiträge. Vol.13. P.1-49.

Ntemiri K., Saravia V., Angelidis C., Baxevani K., Probonas M., Kret E., Mertzanis Y., Iliopoulos Y., Georgiadis L., Skartsi D., Vavylis D., Manolopoulos A., Michalopoulou P. \& Xirouchakis S.M.N. 2018. Animal mortality and illegal poison bait use in Greece // Environmental Monitoring and Assessment. Vol.190. P.1-16. DOI:10.1007/s10661018-6838-5

Papageorgiou N.K. 1996. [Game breeding.] Thessaloniki: University Studio Press. 242 p [in Greek].

Papageorgiou N.K., Sepougaris A., Christopolou O.G., Vlachos C.G. \& Petamidis J.S. 1988. Food habits of the Red Fox in Greece // Acta Theriologica. Vol.23. P.313-324.

Padial J. M., Avila E. \& Sanchez J. M. 2002. Feeding habits and overlap among red fox (Vulpes vulpes) and stone marten (Martes foina) in two Mediterranean mountain habitats // Mammalian Biology. Vol.67. P.137-146.

Peel M.C., Finlayson B.L. \& McMahon T.A. 2007. Updated world map of the Köppen-Geiger climate classification // Hydrology and Earth System Sciences. Vol.11. P.1633-1644.

Perez-Suarez G., Palacios F. \& Bousrot P. 1994. Speciation and paraphyly in Western Mediterranean hares (Lepus castroviejoi, L. europaeus, L. granatensis and L. capensis) revealed by mitochondrial DNA sequencing// Biochemical Genetics. Vol.32. P.423-436.

Pierpaoli M., Riga F., Trocchi V. \& Randi E. 1999. Species distinction and evolutionary relationship of the Italian hare (Lepus corsicanus) as described by mitochondrial DNA sequencing // Molecular Ecology. Vol.8. P.1805-1817.

Prigioni C. 1996. Distribution of Mammals in Albania // Hystrix. Vol.8. P.67-73.

Reuther C., Dolch D., Green R., Jahrl J., Jefferies D., Krekemeyer A., Kucerova M., Madsen A.B., Romanowski J., Roche K., Ruiz-Olmo J., Teubner J. \& Trindade A. 2000. Surveying and Monitoring Distribution and Population Trends of the Eurasian Otter (Lutra lutra) // Habitat. Vol.12. P.1-152.

Roos A., Loy A., de Silva P., Hajkova P. \& Zemanová B. 2015. Lutra lutra. The IUCN Red List of threatened species 2015. e.T12419A21935287. DOI:10.2305/IUCN.UK.2015-2. RLTS.T12419A21935287.en.

Ruiz-Olmo J. 2006. The otter (Lutra lutra L.) on Corfu Island (Greece): situation in 2006// IUCN Otter Specialist Group Bulletin. Vol.23. P.16-24.

Serafini P. \& Lovari S. 1993. Food habit and trophic niche overlap of the red fox and the stone marten in a Mediterranean rural area // Acta Theriologica. Vol.38. P.233-244.

Sliwinski K., Ronnenberg K., Jung K., Strauß E. \& Siebert U. 2019. Habitat requirements of the European brown hare (Lepus europaeus Pallas 1778) in an intensively used agriculture region (Lower Saxony, Germany) // BMC Ecology. Vol.19. P.1-11. DOI:10.1186/s12898-019-0247-7

Smith R. K., Jennings N. V. \& Harris,S. 2005. A quantitative analysis of the abundance and demography of European hares Lepus europaeus in relation to habitat type, intensity of agriculture and climate // Mammal Review. Vol.35. P.1-24.

Sommer R. \& Benecke N. 2004. Late- and Post-Glacial history of the Mustelidae in Europe // Mammal Review. Vol.34. P.249-284.

Sordinas A. 1969. Investigations of the prehistory of Corfu during 1964-1966 // Balkan Studies. Vol.10. P.393-424.

Spassov N., \& Acosta-Pankov I. 2019. Dispersal history of the golden jackal (Canis aureus moreoticus Geoffroy, 1835) in Europe and possible causes of its recent population explosion // Biodiversity data journal. Vol.7. P.e34825. DOI:10.3897/BDJ.7.e34825.

Stille B. \& Stille M. 2017. The Herpetofauna of Corfu and Adjacent Islands. Frankfurt Contributions to Natural History Vol.65. Frankfurt am Main: Edition Chimaira. $354 \mathrm{p}$.

Stille M., Gasteratos I. \& Stille B. 2021. Alien and invasive terrestrial vertebrate species on Corfu, Ionian Islands, Greece // Journal of Vertebrate Biology. Vol.70. P.20126. DOI: $10.25225 / \mathrm{jvb} .20126$

Tack J. 2018. Wild boar (Sus scrofa) populations in Europe: A scientific review of population trends and implications for management. Brussels: European Landowners' Organisation. $56 \mathrm{p}$.

Theotokes E. 1826. Détails sur Corfoú. Corfou. 148 p.

Tsachalidis E.P. \& Hadjisterkotis E. 2009. Current distribution and population status of wild boar (Sus scrofa L.) in Greece // Acta Silvatica et Lignaria Hungarica: An 
International Journal in Forest, Wood and Environmental Science. Vol.5. P.153-157.

Urban P. 1998. Eurasian otter (Lutra lutra L.) in the NorthWestern Greece - contribution to distribution, limiting factors and conservation measures //Vydra. Vol.8. P.44-47.
Vaughan N., Lucas E., Harris S. \& White P. C. L. 2003. Habitat associations of European hares Lepus europaeus in England and Wales: Implications for farmland management // Journal of Applied Ecology. Vol.40. P.163-175. 